\title{
Faith in God, philanthropy and foundations of criticism of religious violence in Mulla Sadra's philosophy
}

\begin{tabular}{|c|c|}
\hline \multicolumn{2}{|c|}{$\begin{array}{l}\text { Authors: } \\
\text { Sayyed M. Emami Jome }{ }^{1} \text { (D) } \\
\text { Mahdi Ganjvar }{ }^{1} \text { (D) } \\
\text { Nafiseh Ahl Sarmadi }^{1} \text { (D) }\end{array}$} \\
\hline \multicolumn{2}{|c|}{$\begin{array}{l}\text { Affiliations: } \\
\text { 'Department of Islamic } \\
\text { Philosophy and Theology, } \\
\text { Faculty Theology and } \\
\text { Ahlul-Bayt's Studies, } \\
\text { University of Isfahan, Isfahan, } \\
\text { Islamic Republic of Iran }\end{array}$} \\
\hline \multicolumn{2}{|c|}{$\begin{array}{l}\text { Corresponding author: } \\
\text { Mahdi Ganjvar, } \\
\text { m.ganjvar@Itr.ui.ac.ir }\end{array}$} \\
\hline \multicolumn{2}{|c|}{$\begin{array}{l}\text { Dates: } \\
\text { Received: } 20 \text { Apr. } 2020 \\
\text { Accepted: } 06 \text { July } 2020 \\
\text { Published: } 30 \text { Sept. } 2020\end{array}$} \\
\hline \multicolumn{2}{|c|}{$\begin{array}{l}\text { How to cite this article: } \\
\text { Emami Jome, S.M., } \\
\text { Ganjvar, M. \& Ahl Sarmadi, N., } \\
\text { 2020, 'Faith in God, } \\
\text { philanthropy and foundations } \\
\text { of criticism of religious } \\
\text { violence in Mulla Sadra's } \\
\text { philosophy', HTS Teologiese } \\
\text { Studies/Theological Studies } \\
76(1), \text { a6046. https://doi. } \\
\text { org/10.4102/hts.v76i1.6046 }\end{array}$} \\
\hline \multicolumn{2}{|c|}{$\begin{array}{l}\text { Copyright: } \\
\text { (C) 2020. The Authors. } \\
\text { Licensee: AOSIS. This } \\
\text { work is licensed under } \\
\text { the Creative Commons } \\
\text { Attribution License. }\end{array}$} \\
\hline \multicolumn{2}{|l|}{ Read online: } \\
\hline 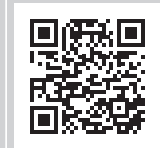 & $\begin{array}{l}\text { Scan this QR } \\
\text { code with your } \\
\text { smart phone or } \\
\text { mobile device } \\
\text { to read online. }\end{array}$ \\
\hline
\end{tabular}

This article aims at showing the potentiality of Transcendent Theosophy (Al-Hikmah Al-Muta'aliyah) in the creation of peace and denial of religious violence. Belief in Necessary Being that is identical to beauty and perfection is one of the central issues in Islamic philosophy, particularly Mulla Sadra's Transcendent Theosophy. This belief has different stages, the highest one of which is a love-based sense of humbleness before God who is the source of beauty. Thus, faith in the thought of Mulla Sadra is one of the aesthetic categories. Surrender to such a Being leads to love in him and his effects. Thus, in Transcendent Theosophy, love in God is followed by the love in people. This love is associated with the sense of responsibility and the effort for the realisation of people's rights. In the final part of the article under the title 'Mulla Sadra and Confrontation of Two Types of Religious Understanding', through the analysis of Mulla Sadra's dialogue with a religious radical, we have criticised the discourse of religious violence and concluded that Transcendent Theosophy is a defender of human rights and a pioneer of peace and a despiser of religious violence. The most important finding of this study is that according to Mulla Sadra, religious radical interpretations are the source of the emergence of religious violence, and the solution to this problem is the promotion of rational and conscious religiosity. The method used in this research is of descriptive-analytic type.

Contribution: The article brought to fore the potentiality of Islamic philosophy for the realisation of peace and the denial of religious violence. The authors analytically studied Mulla Sadra's pacifist foundations in order to ascertain its relation with non-violence towards humans. The main contribution of this article is that the teachings of Transcendent Theosophy are very useful for creating peaceful coexistence between human beings.

Keywords: peace; religious violence; faith; love in people; Mulla Sadra.

\section{Problem statement}

Human history has been witness to the violence of humans against each other in the name of religious belief and sense of responsibility before God. We have experienced its horrible example in our age in the Middle East region. In these acts of violence that have occurred in the name of religion and implementation of divine precepts, many people are killed and numerous women and children are violated and enslaved.

Our problem is raising the following basic question: whether belief in God and the sense of responsibility before the Lord whom we worship really lead to the occurrence of such violent actions?

The fundamental focus of this article is presenting this question to Mulla Sadra and his philosophical school that if the belief in a God who has all perfections and beauties could result in such violent and ruthless consequences?

Although Mulla Sadra is the founder of a new philosophical school called Transcendent Theosophy, he is an heir to a philosophical current established by Farabi and Avicenna. Accordingly, we believe that a short discussion of the views of these two philosophers concerning the aesthetic content of belief in God is necessary as far as the scope of the article allows. Then, we will continue to examine the view of Mulla Sadra and its consequences in full detail.

Generally speaking, the problem of peace and nonviolence is considered to be one of the significant issues of political philosophy, for 'the topics that the political philosophy discusses include justice, freedom, liberty, utopia, human nature, rights, duties, social control, peace, war and so on' (Ali \& Qin 2019:1). On the one hand, some of these sociopolitical issues (Ali \& Qin 2019):

$[S]$ tart with the religion Islam and the unification of spiritual and political authority in one person, Muhammad, who established the city-state of Medina, a model for Muslims till this day. (p. 2) 
On the other hand, Islamic philosophy defines its goal as theomorphism (imitatio Dei) and changing oneself into the Perfect Man (Mulla Sadra 1981 1:20). Perfect Man as the deputy of God on earth is the promoter of tolerance and peace and the despiser of oppression and violence, because 'he is the source of mercy for all human beings around the globe and the comprehensive manifestation of Divine Compassion (Mulla Sadra 2008 2:204). On the other hand, we know that 'violence is potentially present in every human being. Violence is part of human nature' (Beyers 2018:3).

Hannah Arendt (2003:18) indicates how violence is committed by normal people who act on temptation to do evil. Her research on wartime atrocities illustrates that normal people are capable of horrid and violent acts. Nevertheless, the invitation to peace and mercy is very clear in the behavioural tradition of prophets, particularly those of the Holy Prophet of Islam. For example, in the sources of Sunni Muslims, it has been quoted that a person once asks the Holy Prophet of Islam to curse someone but his Highness stated: I have not been delegated for cursing rather I am Divine Mercy for all creatures in the universe (Ganjvar 2019:135). Then, he sends a moral message of tolerance to all people (Bukhari 1998:4):

Don't harbor anyone's grudge into your hearts. Don't be jealous of each other and do not turn your back to anyone. You all are the servants of God and brothers. (p. 252)

Undoubtedly, one of the factors of success of the prophets, in particular the prophet of Islam (peace be upon him [p.b.u.h.]), has been their good temper and mildness in words and practice. According to Qur'an, the soft-natured attitude of the prophet of Allah (p.b.u.h.) in interaction with the people has been one of the main factors in attracting them towards Islam (Maaref 2018:4). The Qur'an states:

It is part of the mercy of Allah that you were lenient with them. And if you had been rude [in speech] and harsh in heart, they would have disbanded from about you. (Qur'an 3:159)

These pacifist Islamic doctrines have deeply influenced Mulla Sadra's thought. This is why his method for the resolution of the crisis of religious violence is the reliance on 'Book and Wisdom'. To put it otherwise, he believed that the main source of animosity and massacre in the name of religion and God is ignorance and religious deviation, and he sought for the way out of these violent situations in reliance on reason and rationalism in religion (Mulla Sadra 2008 7:191).

Thus, Islamic philosophy struggles after the realisation of the maximum peace and good for all human beings, and pacifism and love of people have been always among the central concerns of the Muslim theosophers. Here, we continue to discuss the foundations of the denial of violence in Mulla Sadra's philosophy.

\section{Who is the subject of faith in God?}

It is needless to say that people's way of life is a function of their perspective of life. No doubt, human perception of himself, humanity, the world in which he lives, existence or non-existence of God and his knowledge of the God in whom he believes play a key role in the formation of human life and his behaviour on the scene of individual, family and social life.

It is very important to know the identity, characteristics and behaviour of the One in whom we believe, and it has a considerable influence on the social functions of the faith. In general, we can speak of three types of faith in God that finally in the domain of the 'who-ness' of God lead to three diametrically different pictures of God: God of slaves, God of merchants and God of lovers.

As to the basis of this classification, one can state that surrender to God is either out of enthusiasm or out of fear. If it is out of enthusiasm, it is either an enthusiasm for the Lord (i.e. aiming at nearness to Divine Presence) that is a 'love-based devotion' or is an enthusiasm for paradise (i.e. out of the thirst for bounties and pleasures of paradise), which represents a 'commercial devotion'. If the surrender is out of fear, it is the 'servitude of servants', the servants who fear their master. Therefore, the God of slaves is a very violent, oppressive and revengeful God. It is a God who is waiting for the occurrence of a mistake by his servant may he punishes him. The God of merchants just knows transaction; it is a God with whom one should speak in the language of merchants; the God who asks for the devotion in return of paradise; but the God of lovers is the God of love, thrill and mirth. Mulla Sadra christens this third category as the 'Delivered Ones', that is, those who have delivered themselves from the bondage of low animal pleasures and lusts (Mulla Sadra 2008 5:259).

In the first perspective, God is worshipped out of fear of punishment, whilst in the second perspective, God is worshipped out of the lust for reward; finally, in the third perspective, God is worshipped as the Beloved where love requires sincere devotion and surrender (Razi 1999; Hekmat:237).

There is a particular series of obligations in all three perspectives, but in the first and second perspectives, if someone fails to meet these obligations, he would face painful torments or lose the paradise and its bounties. However, in the third perspective, these prescripts and obligations serve as the signs that lead one to the Beloved.

It is needless to say that these three perspectives give rise to three forms of life and three forms of interaction with others. For depending on the God before whom one finds himself, he will make use of different etiquettes: if this God is a prison keeper or a slaver, or a God who is a partner to the transaction or a God who is the beloved. In short, in the presence of the prison keeper, the ethics of slaves will be realised, whilst in the presence of a merchant, one will need to keep with the buyer's ethics; finally, in the presence of the Beloved, it is the love ethics that will become realised (Soroush 2013 2:164-165). 


\section{Philosophical background of Mulla Sadra on the belief in love and beauty}

Here we do not intend to discuss the issue of love and beauty and its relationship with faith in Islamic philosophy, because it lies outside the scope of this article. As the title suggests, the main axis of our discussion is the philosophy of Mulla Sadra, and here we only struggle to shortly allude to the philosophical background of Mulla Sadra. Accordingly, we refer to the aesthetic perspective of Farabi and Avicenna as the pioneers of Islamic philosophy.

Avicenna refers to God as Necessary Being. He also considers him to be identical with beauty and the source of beauties, and because he is self-conscious and in this self-consciousness it is all beauty that is the beholder and the seen, then he is thoroughly love and mirth. Divine Essence is indeed the first and the greatest Lover and Beloved (Avicenna 1984:368-369).

In fact, in Islamic philosophy, including Avicenna's philosophy, love and jubilation have their origin in aesthetic consciousness, and because God is essentially self-conscious and identical with beauty, then by his Nature, God owns love and jubilation (Avicenna 1984:368-369).

It is noteworthy that in his aesthetics, Avicenna insists on the notion of 'moderation' as one of the main key aesthetic words in Islamic theosophy and thought. This insistence unavoidably leads to the definition that he offers of beauty (Avicenna 1984):

God is the Origin of beauty and pure Beauty and the source of all beauties in the world and this is why He is the source of all moderation in the world. (p. 370)

Thus, Avicenna has come to believe in the current of love in all worlds based on the idea that the truth of Divine Essence is love, beauty and mirth, and the philosophy of creation is nothing but the circulation of love and beauty. It is under the inspiration of such a belief that he has written the 'Essay on Love', and at the end of it, he concluded that all beings in the existential spheres - which of course, contain the man and human world too - are in love with good and beauty (Avicenna 2009:393-396). This is why in Avicenna's philosophy not only man and philanthropy have been simultaneously underlined, they are also highlighted (Mahdi \& Lerner 1963):

$[A] \mathrm{s}$ man is ordered naturally to God through the reverence due Him, so he is ordered to his neighbor by justice and peace, and to himself by honorableness of life. (p. 360)

To be sure, a philosophy that forms based on such a foundation cannot accept antihuman violence. In such a philosophy, peace and security are considered to be a fundamental principle.

Farabi (1926a, 1926b) as a philosopher has also spoken of love and beauty in his philosophy and in his numerous essays including 'Al Da'wi Al Qalbyyah' [Cordial Claims] and 'Al Ta'liqat' [Annotations]; he struggles to explain the philosophy of creation in terms of the philosophy of love and jubilation because God is continuously creating; this is why he is one with beauty and has consciousness and love of beauty and has willed these beauties to be reflected and manifested (Farabi 2002:60).

The whole reality of love lies in the Essence of Divinity, and this is why he has blessed the creatures out of his Compassion in order to pave the path for them to reach their existential ends and evolve (Farabi 2002:82). Indeed, Farabi as an Islamic philosopher has considered the divine creation to have its origin in Divine Love in beauties and their distribution through the lower steps of the hierarchy of existence.

Farabi before Avicenna, at the end of his 'Essay on Acquisition of Prosperity', has discussed these issues that a philosophy that is not based on honesty, justice-seeking, support of justice-seekers and denial of oppression to humans is a baseless philosophy (Farabi 1927:44-45).

Surely, Farabi's pro-justice perspective that entails philanthropy and observation of human rights has its origin in his aesthetic vision of existence and God who is the creator of this world. But because among different goods and objectives of man, the most important one of which is 'peaceful life' and because this is acquired more than anything else through justice (Mahdi \& Lerner 1963:429), Muslim philosophers from Farabi to Avicenna and Mulla Sadra have all insisted on the exercise of justice in the human city because these philosophers inspired by religious doctrines have recognised that it is only under the shadow of social justice that tensions and violence disappear and peace prevails the life of residents of the city.

Under the influence of Plato, Farabi believes that 'the king should try to make his reign to be in the image of the cosmic rule of god, a rule characterized by order, peace, and goodness' (O'Meara 2005:219). 'Alfarabi enumerates 12 qualifications for the ruler of his virtuous city' (Ali \& Qin 2019:4), one of the most important ones of which is the love of 'justice and of just people', and hatred for 'oppression and injustice and those who practice them' (Farabi 1985:247-249). This is to say that the ruler should be in love with justice and just people and avoid all types of oppression, violence and stubbornness in the management of city affairs.

He should love justice and just people and not be headstrong or a wrangler about what he desires. He should be pious, yield easily to goodness and justice, and be stubborn in yielding to evil and injustice (Parens 2007:32). One man ruling according to virtue will be more capable of preserving peace, and the peace of the citizens will not be so easily disrupted (Mahdi \& Lerner 1963:407). 
It is totally clear that when a government has such a philosophical background as well as such a righteous and pacifist ruler, the citizens will coexist in full peace, and conflict and violence will disappear from that society.

'Alfarabi, on the other hand, seeks perfection for all the inhabitants of his city' insofar as one can describe Farabi's Utopia a 'program for Muslim revival' and their rational and spiritual evolution towards the realisation of moralsocial virtues such as justice, peace and security for the inhabitants of the city (see Ali \& Qin 2020:2-3).

He believes that whenever divine virtues become realised in the soul of humans, the people of the city in their attributes and actions become similar to God, and for this reason, they approach their fellow humans in the spirit of divine love. In this way, the city will turn to a secure territory full of peace, justice and love insofar as even the ruling laws of it are regulated in a way that finally it leads to the strengthening of peace and justice and denial of violence among the citizens (Mahdi \& Lerner 1963:365).

Therefore, this is why some scholars such as Parens have considered Farabi to be the 'Great Defender of Peace and Justice' in the Islamic world (Parens 2007:80).

In addition to Farabi and Avicenna, Mulla Sadra has also identified pleasure, jubilation, love and mirth with existence and perfection and believes that every creature has a share of jubilation, love and mirth proportionate to its share of perfection and existence. As God is pure existence and absolute perfection and one with the consciousness of his Truth, he is essentially of beauty, jubilation and mirth (Mulla Sadra 1981 9:122-125, 6:340, 4:122).

In this regard, in his 'Mabda' va Ma'ad' [Origin and Return], Mulla Sadra has opened a chapter entitled 'Chapter on the Truth that God Rejoices in His Essence' that expresses the importance of the aesthetic domain in God's ontology (Mulla Sadra 2001:247). Therefore, in Islamic philosophy, particularly in Mulla Sadra's philosophy, faith in God is indeed the faith in love and represents the source of beauty, jubilation and mirth.

\section{Sense of responsibility resulted from love in God and its possible negative consequences}

Thus conceived, faith in God is based on a series of different modes of consciousness and knowledge that have been acquired concerning God. However, according to an Islamic philosopher, particularly Mulla Sadra, this aesthetic consciousness and knowledge and the object of the latter are perfections and beauties owned by God. Accordingly, thus conceived, God is not just the creature who is known through his power and dominance, and we need to follow his orders; rather, he is a lovely entity and deserves to be loved. His creation is not just an act of power and domination; rather, it has its origin in love and jubilation. In fact, with his omnipotence, God wants his beauties to be revealed and his perfections to be distributed. Here a rule prevails which is considered to be among the basic foundations of Mulla Sadra to the effect that love is identical and coextensive with knowledge; and intensity and weakness of love are a function of the intensity and weakness in knowledge' (Mulla Sadra 2002:100).

Of course, one needs to take into account that love in this context does not represent an emotional and instinctual attachment; rather, this sense of love is based on an aesthetic consciousness. In other words, when the man becomes conscious of perfections, beauties and goodness which are hidden in something, love is acquired in proportion to the beauties and the consciousness that one has of those beauties.

However, a great problem in the size of a social crisis in regional or even global scale can occur. When faith is full of the love of God, it will be filled with the sense of responsibility and accomplishment of one's obligations towards him. Thus, a powerful motive is created for action. Now if these phenomena are associated with egotism and religious and ethnic prejudices and involve personal tastes in religious affairs, this will possibly result in the outbreak of violence and violation of human rights.

Nevertheless, Mulla Sadra, in his aesthetic analysis of faith, combines knowledge and love and uses the love of God as a platform to reach the love of humans and likewise the sense of responsibility before him as a foothold to realise the sense of responsibility before humans and fulfilment of their rights, which will be discussed below.

\section{From the love of God to the love of people}

Mulla Sadra argues that when we reach the love of God through his knowledge of beauties as well as his majesty and magnificence which is one and the same with his Mercy and Compassion, the love of people turns unavoidable. Here Mulla Sadra has a fundamental maxim: 'love of everything is associated with the love of its effects'. To put it otherwise, 'love of the cause is also the love of its effect'. Therefore, love of people is the same with the love of God given they're being the effect and creature of God' (Mulla Sadra 2002:108).

The meaning of Mulla Sadra's remarks is that the love of God or the love of a man is not separated from the love of God or his effects. All creatures including humans are created by God. Then, they are considered to be his effects, and if someone loves God, he cannot lack the love of people and all human beings. Thus, care and compassion towards people are among the effects of the love of God. In his exegesis of the Quran, Mulla Sadra describes the love of creatures as a function of the love of God and considers the love of people to be a sign of the true mystics (Mulla Sadra 2008 7:260). 
It is interesting to note that Mulla Sadra has not sufficed to love and care and argued that the realisation of the rights of creatures depends on the love of God and the love of people (Mulla Sadra 2008 7:260). Thus, according to Mulla Sadra, the higher ascends the mystic in the level of mysticism, the more his love of God and the people increases due to the increase of his knowledge, and this love leads him to fulfill the rights of the people.

An example of this type of ideological-emotional transformation can be seen in the mystical character of Muhy Al-Din Arabi who introduced himself as the 'follower of the religion of love'. Through devotion and spiritual initiation, he reached the truth that: 'the divinely revealed paths lead to the same summit and that to have lived one religion fully is to have lived them all' (Nasr 1997:118). He expresses this mystical truth in his renowned poem as follows (Nasr 1997):

My heart has become capable of every form; it is a pasture for gazelles and a convent for Christian monks;

And a temple for idols and the pilgrim's Ka'ba and the tables of the Torah, and the book of the Qoran.

I follow the religion of Love; whatever way Love's camels take, that is my religion and my faith. (p. 118)

Thus, one should say that love of God and people is not merely an emotional and moral love and attachment; rather, there is a sense of deterrence associated with a sense of responsibility before people. One of its requirements is the defence of the rights of people before those who commit evil actions and trespass the rights of God and people and defy God and are his enemies (Mulla Sadra 2002:107).

In other words, one of the effects and signs of the love of God is the compassion and love one shows towards the creatures and servants of God. However, on the other hand, one should battle against those who are the enemies of God and people and commit oppression and evil things exactly out of the love of God and people.

However, one has to be careful even in this battle not to use every means in order to reach a goal, because Mulla Sadra, as a Muslim theosopher who follows Quran, believes that goal does not justify the means. Thus, to reach a sacred goal, one cannot resort to prejudice and violence even if that goal is an invitation to God and religion (Mulla Sadra 2008 4:340):

Call to the way of your Lord with wisdom and goodly exhortation and have disputations with them in the best manner. (Qur'an 16:125)

\section{Mulla Sadra and the opposition between two types of understandings of religion}

Although there are countless points in the sacred text where tolerance is noticed, we still are faced with ideas that pretend to be religious, on the one hand, and do not have any weapon but violence. Holy Prophet of Islam has reminded Imam Ali of the necessity of self-possession and tolerance in religion. Prophet asks Imam Ali to approach Islam in the spirit of tolerance (Koleini 1984 2:86).

In Islamic philosophy, the founder of Transcendent Theosophy, Mulla Sadra, has depicted two types of understanding of religion based on his notion of faith in God focusing on the love of God and the love of people. In his discussion of this opposition, he proceeds to provide an analysis and indeed a criticism of that understanding of religion that ends up in violence against people:

1. There is a group of religious scholars who because of their specific understanding of religion have considered all belief and creed other than theirs to be blasphemy and animosity with God and do not tolerate any belief other than the one in which they believe themselves. These scholars kindle the fire of toughest forms of violence against the people who do not share their religious beliefs. Of course, there is no doubt that 'Some of the religious rituals provoke violence among believers' (Masango 2018:3). For example, one can refer to the aggressive behaviours that are shown in the name of religion or 'Enjoining Good and Forbidding Wrong' in violent and hatred based forms though all with a religious appearance including the brutal and insulting treatment of women on the pretext of promotion of Hijab and battle with bad Hijab in some Islamic societies.

Moreover, one can refer to the religious ceremony of 'Tatbtir' (Trauma) that has turned to an official and sacred ritual in some Shia Muslim countries and is expanding every day. These religious rituals are prevalent among some Shia Muslims, and in it, people cut their heads with a sharp tool like dagger and bleeding starts. This type of violent mourning is done among a group of Shia Muslims in the ceremonial mourning of Moharram for strengthening the sense of sympathy and expression of devotion towards Hossein Ibn Ali (Shia Third Imam) and also for the sake of strengthening the spirit of courage, Jihad and martyrdom in the path of beliefs.

In a study that has been conducted among 200 Iranian students, $12.5 \%$ of the subjects have reported that they have been victims of at least one case of religious violence and abuse. These cases include seeing the blood of sacrificed animals and Tabtir. The researchers of the latter study have concluded that being a victim to the religious violence and abuse and ritualisation in general, and Tabtir in particular, can play a significant role in the emergence of mental disorders, for example, Dissociative Identity Disorder (DID) (Nobakht \& Dale 2018:3575-3588).

2. But there is also another type of understanding of religion that allows the religious scholars to let God decide of the people who do not share their own creed and even they ask divine compassion and mercy for them. In this type of understanding of religion, religious 
scholars do not declare someone the enemy of God just under the pretext of having a religion other than theirs. ${ }^{1}$

Mulla Sadra has depicted this opposition in the form of a dialogue that occurs during the reign of Shah Abbas Safavi, the King of the time of the philosopher himself. But this dialogue seems to express the current world condition, particularly the contemporary Islamic world where different religious groups have emerged with their special mechanisms, power arrangement and wealth. These religious groups use different types of violence against various classes of people, even defenceless women and children just based on religious differences.

It is interesting to note that Mulla Sadra refers to these two religious scholars as 'Saviour' and 'Destructor'. The 'Destructor' is the scholar who issues religious fatwa against the people who have different religious creeds that involves their massacre and exile, whilst 'Saviour' represents the scholar who lives in peace even with the people who do not share his own creeds and ask divine compassion and mercy for them. Mulla Sadra describes the 'Destructor' as a man who is suffering from mental disorders and serves neither God nor the Lord's religion; rather, he is at the service of his own faculty of passion. This dialogue that Mulla Sadra has provided in his 'Tafsir Al Quran' [Exegesis of Quran] sufficiently reveals the perspective of Mulla Sadra concerning religion and his criticism of religious violence against the noncoreligionists:

\section{Saviour: How is your life?}

Destructor: I live within divine bounties while I would like them to increase. I am the helper of the Lord's religion and the enemy of God's enemies and declare war against them.

Saviour: Who are the enemies of God?

Destructor: Anyone who is against my religion and belief.

Saviour: What will you do if you dominate them?

Destructor: I invite them to my own religion and creed.

Saviour: If they refuse to accept your invitation, what would you do?

Destructor: I'll kill them and shed their blood and I'll take their wives and children as my own captives or send them to exile.

Saviour: If you fail to dominate them, what will you do?

Destructor: I'll curse them day and night while I read my prayers and I'll do all these as a means of nearness to God.

Saviour: Do you know you'll get nothing out of these curses?

Destructor: I do not know but I would find peace and pleasure in myself and cure my pains when I do what I said.

Saviour: Do you know why you are so?

Destructor: No, I don't know! Can you tell me why I am so?

1.For these two groups with the characteristics that were mentioned for them, in every period of time in ideological societies, one can find numerous examples. Of every period of time in ideological societies, one can find numerous examples. Of course, there is no occasion for naming religious figures belonging to these two groups and it is not even possible. Because these examples vary in view of the perspective of people and everyone in view of the mentioned characteristics can find certain examples for each group in his own time.
Saviour: Because your soul is ill. Your heart and spirit are suffering ... There is no sign of true religiosity in what you have reported and these thoughts and behaviours do not strengthen the religion. You are indeed under the domination of your own carnal soul and faculty of passion that has prevailed you ... Whenever you think that you are promoting the Lord's religion you are indeed under the spell of Satan. You have to know that you are imprisoned in hell unless you deliver yourself from these torments with which you are entangled through common sense.

Destructor: Now you brief me of your ideas and religion and tell me how is your life?

Saviour: OK! Let's see; I am living inside divine bounties which cannot be enumerated and no one can express the due thanks of God for them. I am satisfied with what God has given me and I am insisting on divine judgments and I do not have any ill idea or behaviour towards any creature of God. I do not have any evil intentions regarding them. My soul is in peace and my heart is so extensive that accepts them all and then all creatures of God are immune on behalf of me. I have surrendered myself to God and my religion is that of Abraham and I say what he said. He said: 'Whoever follows me, he is part of my people and whoever revolts against me and You Allah are the most forgiving and compassionate' (Quran 14:36). He also said: 'If you punish them, they are your servants and if you forgive them, you are Greatest and All-Wise.' (Quran 5:118; Mulla Sadra 2008 6:218-220), [End of Dialogue]

Although Mulla Sadra has chosen this dialogue from the series of various stories and dialogues from Ikhwan Al Safa Essays (Ikhwan Al Safa 1992 3:312-313) and related it in his 'Tafsir Al Quran', he has recited this dialogue first as the confrontation of two logics and ways of understanding of religion one of which does not lead but to violence and creation of evil and destruction of people's security and peace in the name of promotion and strengthening of religion in the society, whilst the other one represents a rational understanding of religion associated with such requirements as love and care of people and avoidance from violence against people who live with their own creeds. Of course, in a second way, there is also a dialogue of the content of religious beliefs of each other and their criticism. Second, Mulla Sadra has argued that the first way of thinking has been current in his own time and this point as a historical report of Mulla Sadra's era is very thought-provoking.

Moreover, Sadra in a poem in his 'Essay on Three Principle' not only refers to the difference of religions but also describes his own religion as the 'religion of love' and speaks of the peace and purity of this religion (Mulla Sadra 2011:7). It is this religion of love that has led him to the tolerant behaviour with the followers of other religions and denominations. He puts this idea as follows, 'My religion is mine and people's religion is theirs' (Mulla Sadra 2011:7). ${ }^{2}$

At the end of the aforementioned dialogue, Mulla Sadra has noted two key points:

2.Compare this statement by a medieval thinker of an Islamic origin with the following maximvor my nim my neighbor to say there are twenty gods or no god. It neither picks my pocket nor breaks my leg (Jefferson 2004:394) and you will know the true value of a man of belief who believes in freedom of expression and toleration in a tradition that has regretfully become known as the source of radicalism. 
First, there are several examples of this type of belief that can make humans suffer, and unfortunately, religious people can justify their violent actions in the name of God. 'In this way, we are able to justify our acts of violence in the name of God' (Masango 2018:2).

Second, Mulla Sadra clearly argues that as long as humans fail to leave these corrupted and violent beliefs behind they will not be able to know God in a true way (Mulla Sadra 2008 6:220).

\section{Conclusion}

1. Islamic philosophy describes 'Imitation of God' and turning man to the Perfect Man as its own goal. Perfect Man is the Caliph of God on earth, a man of peace, and an opponent of oppression and violence. The Last Prophet Mohammad is better known as 'Mercy for Two Worlds' and brings the message of peace and love to all people across the globe.

2. The political philosophy of Farabi and Avicenna is founded based on pacifism, love in justice-seekers, and denial of oppression and violence towards humans. No doubt, this pacifist and pro-justice approach of Muslim philosophers implies philanthropy and observation of the rights of fellow humans and is rooted in their aesthetic vision of the universe as well as in the Creator of this universe.

3. Mulla Sadra's Transcendent Theosophy as a developed school of Islamic philosophy is also seeking to realise peace and goodness for all humans in a way that pacifism and philanthropy have always been the way and method of this Muslim philosopher.

4. Thus, it became clear that Mulla Sadra's method for the resolution of the crisis of religious violence is the reliance on 'Book and Wisdom'. Ignorance and religious radicalism is the main cause of hatred and killing in the name of religion and God, and the way out of this violence is the reliance on rational religiosity.

5. Theology as the main core of religiosity is of paramount importance in this context. God by his nature owns all beauties and his knowledge of his essence is his knowledge of his beauties as such. Then, he has essential jubilation and love.

6. This essential love and jubilation is the philosophy of creation, and the latter is the manifestation and distribution of his majesty and beauties.

7. His love of his own essence requires to be associated with his love of his creatures because they are manifestations of his beauties.

8. Thus, one should state that humankind is a particular manifestation of God's beauties and he has a special love and care of humans.

9. A true man of faith loves God, and this love requires him to love God's effects; as humankind is a special and chosen effect of God, then the true man of faith loves humankind, and it is exactly in this point where antihuman violence is in conflict with true faith.
10. Mulla Sadra refers to Destructor and Saviour as the symbol of two types of religious scholars. He believes that a scholar who insists on his own religious notions and considers only himself to be right whilst accusing others of being deviated and uses utmost violence and ruthlessness against his opponents is exposed to destruction. He believes that such a mindset is the source of death and destruction, and the owner of such a mentality is described as the Destructor. On the other hand, a scholar who interacts with non-co-religionists and thinkers from different intellectual backgrounds in the spirit of peace and love, he is considered to be prosperous and a man of salvation.

11. According to what was said, Islamic philosophy in general, and Mulla Sadra's philosophy, in particular, can be declared the pioneer of peace and security and peaceful coexistence between humans and a defender of human rights away from all types of religious violence.

\section{Acknowledgements Competing interests}

The authors have declared that no competing interests exist.

\section{Authors' contributions}

The research was carried out by M. Ganjvar and N.Saradi under the supervision of Prof. M. Emami Jome.

\section{Ethical consideration}

This article followed all ethical standards for carrying out research without direct contact with human or animal subjects.

\section{Funding information}

This research received no specific grant from any funding agency in the public, commercial or not-for-profit sectors.

\section{Data availability statement}

Data sharing is not applicable to this article as no new data were created or analysed in this study.

\section{Disclaimer}

The views and opinions expressed in this article are those of the authors and do not necessarily reflect the official policy or position of any affiliated agency of the authors.

\section{References}

Ali, I. \& Qin, M., 2019, 'Distinguishing the virtuous city of Alfarabi from that of Plato in light of his unique historical context', HTS Teologiese Studies/Theological Studies 75(4), a5370. https://doi.org/10.4102/hts.v75i4.5370

Ali, I. \& Qin, M., 2020, 'City and soul in Plato and Alfarabi: An explanation for the differences between Plato's and Alfarabi's theory of city in terms of their distinct psychology', Axiomathes 30, 91-105. https://doi.org/10.1007/s10516-01909439-w 
Arendt, H., 2003, Responsibility and judgment, Schocken Books, New York, NY.

Avicenna, H.A., 1984, Al Shifa: Theology, Manshurat Maktabah Al Mara'shi Al Najafi, Qom.

Avicenna, H.A., 2009, 'Risalah Al-Ishq (essay on love)', in S.M. Taheri (ed.), Avicenna's collected works, pp. 393-396, Ayatollah Eshraq Press, Qom.

Beyers, J., 2018, 'Religion and violence: Shutup Shylock', HTS Teologiese Studies/ Theological Studies 74(3), a5165. https://doi.org/10.4102/hts.v74i3.5165

Bukhari, M.I.E., 1998, Sahih Al Bukhari, Dar Al Fikr, Lebanon, Beirut.

Farabi, A.N., 1985, Mabadi Ara Ahl al-Madina al-Fadhila, transl. R. Walzer, Clarendon Press, Oxford.

Farabi, A.N., 1926a, 'Al Da'wi Al Qalbyyah', in Rasa'el Al Farabi, pp. 118-129, Matba Majles, Hyderabad.

Farabi, A.N., 1926b, 'Al Ta'liqat', in Rasa'el Al Farabi, pp. 65-91, Matba Majles, Hyderabad.

Farabi, A.N., 1927, 'Tahsil Al Sa'adah (essay on acquisition of prosperity)', in Rasael Al-Farabi (ed.), pp. 65-91, Ottoman Encyclopedia Press, Hyderabad.

Farabi, A.N., 2002, Fusus Al Hikam, annotated by Seyed Esmaeil Ghazani, Society of Works and Cultural Dignitaries, Tehran.

Ganjvar, M., 2019, 'Islamic model of children's spiritual education (CSE); its influence on improvement of communicational behaviour with non-coreligionists', International Journal of Children's Spirituality 24(2), 124-139. https://doi.org/ 10.1080/1364436X.2019.1624254

Holy Qur'an, 1982, transl. M.H. Shakir, Elmhurst, New York, NY.

Ikhwan Al Safa, 1992, Ikhwan Al Safa's essays and Khullan Al Wafa, vol. 3, Dar Sader, Beirut.

Jefferson, T., 2004, in J. Appleby \& T. Ball (eds.), Jefferson: Political writings, chapter VII: Religious Liberty and Toleration, pp. 389-407, Cambridge University Press, Cambridge.

Koleini, M.I.Y., 1984, Usul al-Kafi, Al Islamiyah Press, Tehran.
Maaref, M., 2018, 'Various types of dialogues and features of a corrective dialogue in the Qur'an', HTS Teologiese Studies/Theological Studies 74(3), a5140. https://doi. org/10.4102/hts.v74i3.5140

Mahdi, M. \& Lerner, R. (ed.), 1963, Medieval political philosophy: A sourcebook, Free Press of Glencoe, New York, NY.

Masango, M.J., 2018, 'Religion, violence and abuse', HTS Teologiese Studies/ Theological Studies 74(3), a5144. https://doi.org/10.4102/hts.v74i3.5144

Mulla Sadra, M.I., 1981, Al-Hikmah Al-Muta'aliyah fi Asfar Al Arba Al Aqlyyah, Dar Ehya Al Turath Al Arabi, Beirut.

Mulla Sadra, M.I., 2001, in J.A.D. Ashtyani (ed.), Al Mabda' va Al Ma'ad, Islamic Promotion Office, Qom.

Mulla Sadra, M.I., 2002, In M. Jahangiri (ed. and intro), Kasr Al Asnam Al Jahilyyah, Sadra Islamic Philosophy Foundation, Tehran.

Mulla Sadra, M.I., 2008, in M. Khajawi (ed.), Tafsir Al Quran Al Karim, Bidar, Qom.

Mulla Sadra, M.I., 2011, in S.H. Nasr (ed.), Essay on three principles, Sadra Islamic Philosophy Foundation, Tehran.

Nasr, S.H., 1997, Three Muslim sages: Avicenna, Suhrawardi, Ibn 'Arabi, Delmar Caravan Books, New York, NY.

Nobakht, H.N. \& Dale, K.Y., 2018, 'The importance of religious/ritual abuse as a traumatic predictor of dissociation', Journal of Interpersonal Violence 33(23), 3575-3588. https://doi.org/10.1080/19349637.2018.1439796

O'Meara, D.J., 2005, Platonopolis: Platonic political philosophy in late antiquity, Oxford University Press, New York, NY.

Parens, J., 2007, An Islamic philosophy of virtuous religions, State University of New York Press, New York, NY.

Razi, S.S., 1999, Nahjol balaghah, Dafter Nashre Farhange Islami, Tehran.

Soroush, A.K., 2013, Wisdom and livelihood, vol. 2, Sirat, Tehran. 